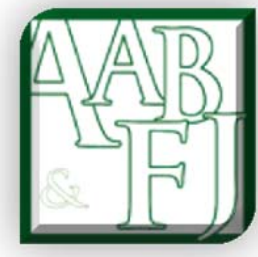

\title{
Editorial Volume 8, Issue 1
}

Ciorstan Smark ${ }^{1}$

The articles published in this issue of AABFJ are drawn from accounting, economics and finance discipline areas. On the finance front, Thorsell and Isaksson (2014) study the experience of directors as a factor determining the success of initial public offerings in Sweden. Yao (2014) examines changes in returns and trading volumes around earnings announcements for firms which have both A-shares (traditionally locally owned) and Bshares (traditionally foreign owned) in China. It considers the impact of regulatory changes which reduced the segmentation of local and foreign investors across the two classes of shares.

From the accounting side, Bhattacharyya (2014) examines the extent of social and environmental reporting in Australia and analyses the association between firm characteristics and the levels of social and environmental reporting using regression analysis. Wheeler, Low and Samkin (2014) examine the perceptions of New Zealand based Chartered Accounting (CA) practitioners of the new directions taken by NZICA with respect to its academic and professional programme requirements to obtain CA Institute membership. Taplin, Yuan and Brown (2014) examine accounting for investment properties by 96 randomly selected Chinese listed companies' year-ending 2008 annual reports. Half the sampled companies use fair value while half use historical cost, both methods being allowable under International Financial Reporting Standards (IFRS) and Chinese Accounting Standards (CAS).

Finally, from economics, Higgs and Worthington (2014) model the price and income elasticity of retail finance in Australia using aggregate quarterly data and an autoregressive distributed lag (ARDL) approach. They focus on the impact of the global financial crisis (GFC) from 2007 onwards on retail finance demand and analyse four submarkets (period analysed in brackets): owner-occupied housing loans (Sep 1985-June 2010), term loans (for motor vehicles, household goods and debt consolidation, etc.) (Dec 1988-Jun 2010), credit card loans (Mar 1990-Jun 2010), and margin loans (Sep 2000-Jun 2010).

\footnotetext{
${ }^{1}$ University of Wollongong, Australia
} 
Smark: Editorial 